$$
\begin{gathered}
\text { D E M O C R A C Y A N D } \\
\text { P O L I T I C A L I G N O R A N C E }
\end{gathered}
$$





\section{E M O C R A C Y A N D P O L I T I C A L I G N O R A N C E}

W H Y S M A L L E R G O V E R N M N T I S S M A R T E R, S E C O N D E D I T I O N Ilya Somin

STANFORD LAW BOOKS An Imprint of Stanford University Press Stanford, California 


\section{Stanford University Press Stanford, California}

(C) 20I3, 2016 by the Board of Trustees of the Leland Stanford Junior University. All rights reserved.

No part of this book may be reproduced or transmitted in any form or by any means, electronic or mechanical, including photocopying and recording, or in any information storage or retrieval system without the prior written permission of Stanford University Press.

Printed in the United States of America on acid-free, archival-quality paper

Library of Congress Cataloging-in-Publication Data

Names: Somin, Ilya, author.

Title: Democracy and political ignorance : why smaller government is smarter / Ilya Somin.

Description: Second edition. I Stanford, California : Stanford Law Books, an imprint of Stanford University Press, 2016. I Includes bibliographical references and index.

Identifiers: LCCN 20I6004872 (print) I LCCN 20I6005766 (ebook) | ISBN 9780804798037 (cloth : alk. paper) I ISBN 97808047993 I 7 (pbk. : alk. paper) I ISBN 9780804799355 (electronic)

Subjects: LCSH: Democracy-United States. I Ignorance (Theory of knowledge) - Political aspects-United States. I Voting-United States. I United States-Politics and government.

Classification: LCC JKI726 .s665 2016 (print) | LCC JKI726 (ebook) | DDC 320.973-dc23

LC record available at http://lccn.loc.gov/20I6004872

Typeset by Newgen in Io/I 5 Sabon 
To my grandparents,

the late Ber and Pauline Somin

and

the late Basya Firun, and Nathan Firun 
